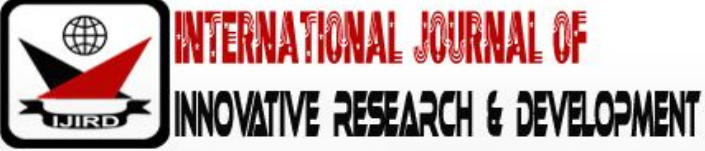

ISSN 2278 - 0211 (Online)

\section{Impact of Physico-Chemical Parameters on Fish Diversity in Gubi Reservoir, Bauchi State, Nigeria}

Suleiman Maigari
M.sc Postgraduate Student, Department of Biological Science,
Abubakar Tafawa Balewa University, Nigeria
Ahmad Jibrin Nayaya
Erofessor, Department of Biological Science, Abubakar Tafawa Balewa University, Nigeria.
Ezalis Gaya
Professor, Department of Biological Science, Abubakar Tafawa Balewa University, Nigeria

\section{Abstract:}

This study is aimed at assessing the impact of physico-chemical parameters on fish diversity in Gubi Reservoir, Bauchi state Nigeria. It was carried out for a period of six months (October 2017-Match 2018). Eight species representing six families were identified. the species identified were include, Clarias garipienus, Oreochromis niloticus, Distichodus engycephalus, Hemichromis fasciatus, Raiamas senegalensis, Labeo senegalensis, Schilbe mystus and Brycinus nurse. Oreochromis niloticus $(70.1 \%)$ was the most abundant fish species while Raiamas senegalensis $(0.01 \%)$ was the least fish species abundant. Water samples for physico chemical parameters were collected, preserved and analysed using standard methods. The physicochemical parameters namely temperature, turbidity, conductivity, total dissolved solids, $\mathrm{pH}$, dissolved oxygen, nitrate, potassium, iron, phosphate and sodium showed significant variation $(\mathrm{P}<0.05)$ for all sampling sites, Conservation measures are encouraged.

Keywords: Impact, physicochemical parameters, fish diversity, Gubi reservoir

\section{Introduction}

Lake and reservoir are habitat of fisheries apart from playing an important role of providing a relatively cheap source of animal protein, it can also provide job opportunities along the capture fisheries value chain and to some extent reduces rural urban drift (FAO, 2014). Anthropogenic processes have physical, chemical and biological impact which modified the reservoir ecosystem (Ahmad and Hussain, 2001; Arharyya, 2005 and Bhagel et al., 2005).The significance of human environmental interaction studies is broadly documented in understanding the impact of human activities on reservoir ecosystem and therefore, require for protection of its further degradation (Abbas and Subramanian, 1984). Ends upon the a biotic factors and types of ecosystem (Nanda and Tiwari, 2001).

The physico-chemical characteristics of a water body is of great value in the determination of productivity, usefulness and other characteristic (Adebisi, 1981; Boyd and Frobish, 1990). Dependence on these water bodies as a valuable resource, demands for adequate understanding of their dynamics, since water is the only medium in which members of the aquatic community live and reproduce. This implies that the aquatic organisms must be able to find shelter and food, make use of dissolved gases in it and reproduce without compromising need for a change environment. The diversity of fish mainly depends upon the a biotic factors and types of ecosystem (Nanda and Tiwari, 2001). Justification of study: Information presented can provide baseline information against which future trend can be measured. The aim of this study is to assess the impact of physico-chemical parameters on fish diversity in Gubi reservoir. Objectives of the study are to determine the composition of fish diversity in gubi reservoir, also to determine the impact of physico-chemical parameters on fish diversity in Gubi reservoir and to determine the correlation between the fish diversity and physico-chemical parameters

\section{Material and Methods}

\subsection{Description of Study Sites}

Gubi reservoir has a total surface area of $590 \mathrm{~km}^{2}$, a depth of $27 \mathrm{~m}$, top crest width of $10 \mathrm{~m}$, base width of $190 \mathrm{~m}$ and has a total catchment area of $179 \mathrm{~km}^{2}$. the surface of the water in Gubi reservoir is mainly coming from three tributaries namely, Gubi river, tagwaye river, link with shadawanka and ran river, is located at firo a village about $12 \mathrm{~km}$ north east of Bauchi metropolis and $8 \mathrm{~km}$ off Bauchi Maiduguri road. 
The primary purpose of providing potable water to Bauchi and its environs. A part from improving water supply to the populace, it provides the bulk of fish consumed in the town as well as providing suitable sites for fadama farming resulting in the production of some highly favoured selected crops (Ezra and Nwankwo 2001). The reservoir lies within the boundary of longitude $10^{0} 25^{\prime} \mathrm{N}$ to $10^{\circ} 26^{\prime} \mathrm{N}$ and latitude $90^{51^{\prime}} \mathrm{E}$ to $9^{0} 52^{\prime} \mathrm{E}$ (Wufem et al 2009).

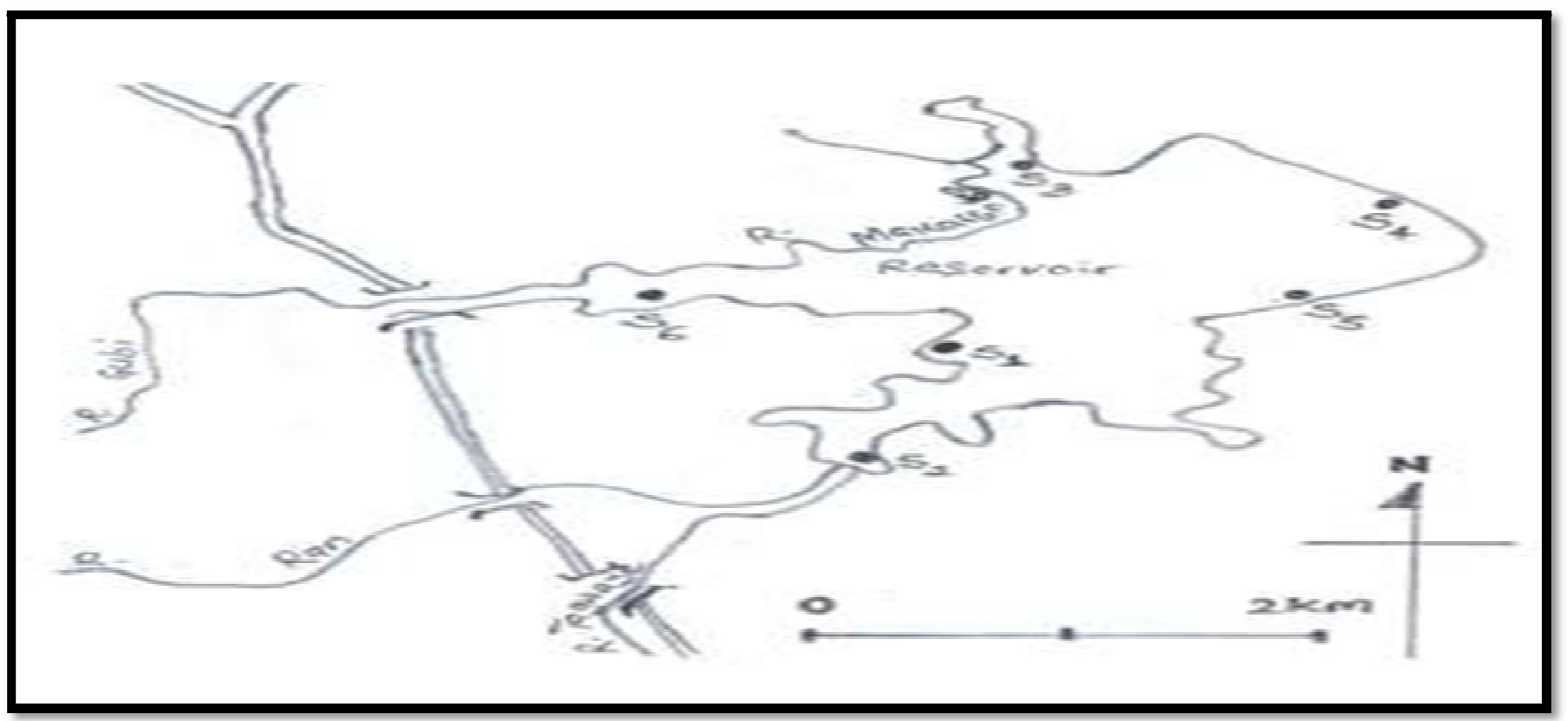

Figure 1: Gubi Reservoir with Its Four Feeding Rivers

\subsection{Sample Collection}

Six sampling sites have been established based on the reconnaissance visit in the study area. The established sampling sites are

- $\quad$ Site $1=$ tatumare

- $\quad$ Site $2=$ kumi

- $\quad$ Site $3=$ baila

- Site $4=$ spillway

- $\quad$ Site $5=$ babban kwata

- $\quad$ Site $6=$ Kwatan yashi

\subsection{Fish Sampling and Identification}

Fish was collected fortnightly from each sampling site for a period of six months with the help of fishermen. Different fishing gears include cast net, gill net, clap net, hook net, burgi net and maley net were used during this study. Collection took place in the morning. Identification of fish has been carried out by using keys following the method described by (Idodo- umeh 2003) and (Froese and pauly, 2015). Fish were identified and sorted out into different species. The relative abundance of each species was expressed as percentage of total catch.

\subsection{Determination of Physico Chemical Parameters}

\subsubsection{Surface Water Temperature}

Surface water temperature was measured in situ on each trip by using mercury bulb thermometer, and the value was recorded in degree Celsius.

\subsubsection{Dissolved Oxygen (DO)}

Dissolved oxygen was measured in situ on each trip by using wagtech DO meter, model no H12400 and the value was recorded in $\mathrm{Mg} / \mathrm{L}$.

\subsubsection{Hydrogen Ion Concentration (PH)}

Water PH was measured on the field with hand by using wagtech PH meter, Model no 2055998. The meter was lowered in to the water and reading was taken immediately.

\subsubsection{Electrical Conductivity and Total Dissolved Solid (TDS)}

These have been estimated using potable wagtech conductivity/ TDS meter. Model no 895049

\subsubsection{Water Transparency/ Turbidity}


2014233

Water turbidity was measured with the hand in the field by each trip by using a wagtech turbidity meter. Model no

2.4.6. Nitrate, Potassium, Phosphorous, Iron and Sodium Ions

These have been determined using atomic absorption spectrophotometers model no 7100

\subsection{Statistical Analysis}

- One-way Anova was used to compare the Physico-Chemical Parameters and fish species diversity between the sampling sites.

- The result obtained was analyzed using descriptive statistics, at $0.05 \%$

\section{Result}

The result of impact of physico-chemical parameters on fish diversity in Gubi reservoir is presented above.

\begin{tabular}{|c|c|c|c|c|c|c|c|}
\hline Fish Species & Tatumari & Kumi & Ba'ila & B/ Kwata & K/ Yashi & Spillway & $\begin{array}{c}\text { Overall Relative } \\
\text { Abundance }\end{array}$ \\
\hline $\begin{array}{l}\text { Oreochromis } \\
\text { niloticus }\end{array}$ & $\begin{array}{c}4596 \\
(70.6 \%)\end{array}$ & $\begin{array}{c}9721 \\
(75.1 \%)\end{array}$ & $\begin{array}{c}4814 \\
(73.3 \%)\end{array}$ & $\begin{array}{c}1446 \\
(44.6 \%)\end{array}$ & $\begin{array}{c}2471 \\
(59.7 \%)\end{array}$ & $\begin{array}{c}2596 \\
(81.9 \%)\end{array}$ & $25644(70.1 \%)$ \\
\hline $\begin{array}{l}\text { Distichodus } \\
\text { engycephalus }\end{array}$ & $247(3.79 \%)$ & $\begin{array}{c}112 \\
(0.86 \%) \\
\end{array}$ & $\begin{array}{c}126 \\
(1.92 \%) \\
\end{array}$ & $\begin{array}{c}40 \\
(1.24 \%)\end{array}$ & $\begin{array}{c}88 \\
(2.13 \%)\end{array}$ & $\begin{array}{c}59 \\
(1.86 \%)\end{array}$ & $672(1.84 \%)$ \\
\hline $\begin{array}{l}\text { Brycinus } \\
\text { nurse }\end{array}$ & $55(0.85 \%)$ & $\begin{array}{c}102 \\
(0.78 \%)\end{array}$ & $\begin{array}{c}261 \\
(3.97 \%)\end{array}$ & $\begin{array}{c}201 \\
(6.21 \%)\end{array}$ & $\begin{array}{c}99 \\
(2.39 \%)\end{array}$ & $\begin{array}{c}98 \\
(3.09 \%)\end{array}$ & $816(2.23 \%)$ \\
\hline $\begin{array}{c}\text { Clarias } \\
\text { gariepinus }\end{array}$ & $65(0.99 \%)$ & $\begin{array}{c}51 \\
(0.39 \%)\end{array}$ & $\begin{array}{c}29 \\
(0.44 \%)\end{array}$ & $\begin{array}{c}39 \\
(1.20 \%)\end{array}$ & $\begin{array}{c}40 \\
(0.96 \%)\end{array}$ & $\begin{array}{c}26 \\
(0.82 \%)\end{array}$ & $250(0.68 \%)$ \\
\hline $\begin{array}{l}\text { Schilbe } \\
\text { mystus }\end{array}$ & $2(0.03 \%)$ & $4(0.03 \%)$ & $\begin{array}{c}1 \\
(0.02 \%)\end{array}$ & $2(0.06 \%)$ & 0 & 0 & $9(0.02 \%)$ \\
\hline $\begin{array}{c}\text { Raiamas } \\
\text { senegalensis }\end{array}$ & 0 & $1(0.01 \%)$ & $\begin{array}{c}1 \\
(0.02 \%)\end{array}$ & 0 & 0 & 0 & $2(0.01 \%)$ \\
\hline $\begin{array}{c}\text { Labeo } \\
\text { senegalensis }\end{array}$ & $31(0.47 \%)$ & $3(0.02 \%)$ & $\begin{array}{c}9 \\
(0.14 \%)\end{array}$ & $\begin{array}{c}16 \\
(0.49 \%)\end{array}$ & 0 & $\begin{array}{c}4 \\
(0.13 \%)\end{array}$ & $63(0.17 \%)$ \\
\hline $\begin{array}{l}\text { Hemichromis } \\
\text { Fasciatus }\end{array}$ & $\begin{array}{c}1506 \\
(23.2 \%)\end{array}$ & $\begin{array}{c}2957 \\
(22.8 \%)\end{array}$ & $\begin{array}{c}1327 \\
(20.2 \%)\end{array}$ & $\begin{array}{c}1493 \\
(46.1 \%)\end{array}$ & $\begin{array}{c}1441 \\
(34.8 \%)\end{array}$ & $\begin{array}{c}386 \\
(12.2 \%)\end{array}$ & $9110(24.9 \%)$ \\
\hline Total & 6502 & 12951 & 6568 & 3237 & 4139 & 3169 & $36566(100)$ \\
\hline
\end{tabular}

Table 1: Relative Abundance of Fish Species in Gubi Reservoir

Table 1shows the relative abundance of fish species in Gubi reservoir. A total of thirty-six thousand

Five hundred and sixty-six of fishes were examined from the fisher's base on the number of sampling sites. Oreochromus niloticus was the most abundance fish species with the overall relative abundance of (70.1\%) showing the prolific nature of tilapia. However, the species of Raiamas senegalensis was the least species abundance with the relative abundant $(0.01 \%)$.

\begin{tabular}{|c|c|c|c|c|c|c|c|}
\hline Parameter & Tatumari & Kumi & Ba'ila & B/ Kwata & K/Yashi & Spillway & Who Standard \\
\hline Temperature $\left({ }^{0} \mathrm{c}\right)$ & 24.5 & 24.2 & 24.6 & 24.4 & 24.8 & 24.8 & $<40^{0} \mathrm{C}$ \\
\hline Ph & 7.61 & 7.49 & 7.65 & 7.83 & 8.07 & 8.16 & $6.5-8.5$ \\
\hline $\begin{array}{c}\text { E.Conductivity } \\
(\mu \mathrm{m})\end{array}$ & 288.6 & 224.8 & 233.25 & 239.7 & 273.8 & 268.2 & 750 \\
\hline TDS $(\mathrm{mg} / \mathrm{l})$ & 165.3 & 142.2 & 147.7 & 149.4 & 155.9 & 145.5 & $1000 \mathrm{ppm}$ \\
\hline Turbidity $(\mathrm{NTU})$ & 18.8 & 12.3 & 27.0 & 14.68 & 20.5 & 16.2 & $5-25$ \\
\hline Iron $(\mathrm{mg} / \mathrm{l})$ & 0.3 & 0.34 & 0.58 & 0.44 & 0.38 & 0.21 & $0.0-0.5 \mathrm{ppm}$ \\
\hline Sodium $(\mathrm{mg} / \mathrm{l})$ & 11.7 & 8.48 & 9.48 & 5.70 & 5.22 & 4.45 & - \\
\hline Potassium $(\mathrm{mg} / \mathrm{l})$ & 7.2 & 6.7 & 5.9 & 6.2 & 5.7 & 5.0 & $0.0-3.0-\mathrm{ppm}$ \\
\hline $\begin{array}{c}\text { Phosphate PO } 4^{-} \\
(\mathrm{mg} / \mathrm{l})\end{array}$ & 15.3 & 9.5 & 7.6 & 9.8 & 10.6 & 6.4 & $0.01-3.0 \mathrm{ppm}$ \\
\hline Nitrate(mg/l) & 3.58 & 3.58 & 4.64 & 4.21 & 5.26 & 6.26 & $0.0-4.0 \mathrm{ppm}$ \\
\hline DO $(\mathrm{mg} / \mathrm{l})$ & 10.5 & 10.5 & 10.4 & 9.9 & 9.7 & 9.1 & $>5 \mathrm{ppm}$ \\
\hline
\end{tabular}

Table 2: Mean Values of Physico Chemical Parameters of Gubi Reservoir at Various Sampling Sites

Table2 shows the physico-chemical characteristics of gubi reservoir. The physico chemical parameters have an important role in supporting fish diversity in fresh water ecosystem. The mean, maximum and minimum values of physico chemical parameters of Gubi reservoir were within the recommended limit by (W.H.O.).

The maximum mean value of surface water temperature $\left(24.8^{\circ} \mathrm{C}\right)$ was recorded between Babban kwata and Kwatan yashi. While minimum mean value of temperature $\left(24.2^{\circ} \mathrm{C}\right)$ was recorded in kumi. 
However, the maximum mean value of $\mathrm{pH}$ (8.16) was recorded in spillway while minimum mean value of $\mathrm{pH}$ (7.49) was recorded in kumi. Similarly, the maximum mean value of Electric. Conductivity $(288.6 \mu \mathrm{m})$ was recorded in Tatumari while the minimum mean value of E. conductivity $(224.8 \mu \mathrm{m})$ was recorded in kumi.

The maximum mean value of total dissolve solid (TDS) $(165.3 \mathrm{mg} / \mathrm{l})$ was recorded in Tatumari while the minimum mean value of TDS (142.2 mg/ l) was recorded in Kumi. The maximum mean value of Turbidity ( $27.0 \mathrm{mg} / \mathrm{l}$ ) was recorded in Ba'ila While the minimum mean value of Turbidity (12.3mg/l) was also recorded in Kumi. The maximum mean value of Iron $(0.58 \mathrm{mg} / \mathrm{l})$ was recorded in Ba'ila, while the minimum mean value of Iron $(0.21 \mathrm{mg} / \mathrm{l})$ was recorded in Spillway.

The maximum mean value of sodium $(11.7 \mathrm{mg} / \mathrm{l})$ was recorded in Tatumari while the minimum mean value of Sodium $(4.45 \mathrm{mg} / \mathrm{l})$ was recorded in spillway. However, the maximum mean value of Potassium $(7.2 \mathrm{mg} / \mathrm{l})$ was recorded in Tatumari, while the minimum mean value of Potassium $(5.0 \mathrm{mg} / \mathrm{l})$ was recorded in spillway. The maximum mean value of Phosphate $(15.3 \mathrm{mg} / \mathrm{l})$ was also recorded in Tatumari. While the minimum mean value of Phosphate (6.4mg/l) was recorded in spillway.

The maximum mean value of Nitrate $(6.26 \mathrm{mg} / \mathrm{l})$ was recorded in spillway while the minimum mean value of Nitrate (3.58mg/l) was recorded Between Tatumari and kumi respectively. However maximum mean value of Dissolve oxygen (DO) $(10.5 \mathrm{mg} / \mathrm{l})$ was recorded between Tatumari and Kumi where the minimum mean value of Dissolve oxygen (DO) $(9.1 \mathrm{mg} / \mathrm{l})$ was recorded in spillway.

\begin{tabular}{|c|c|c|c|c|c|c|c|c|}
\hline Parameters & $\begin{array}{l}\text { Oreochros } \\
\text { Niloticus }\end{array}$ & $\begin{array}{c}\text { Distichodus } \\
\text { Engycephalus }\end{array}$ & $\begin{array}{c}\text { Brycinus } \\
\text { Nurse }\end{array}$ & $\begin{array}{c}\text { Clarias } \\
\text { Gariepinus } \\
\end{array}$ & $\begin{array}{l}\text { Schilbe } \\
\text { Mystus }\end{array}$ & $\begin{array}{c}\text { Raiamas } \\
\text { Senegalensis }\end{array}$ & $\begin{array}{c}\text { Labeo } \\
\text { Senegalensis }\end{array}$ & $\begin{array}{l}\text { Hemichromis } \\
\text { Fasciatus }\end{array}$ \\
\hline $\begin{array}{l}\text { Temperature } \\
\left({ }^{\circ} \mathrm{C}\right)\end{array}$ & -0.672 & -0.168 & -0.068 & -0.530 & -0.984 & -0.495 & -0.263 & -0.839 \\
\hline $\mathrm{pH}$ & -0.756 & -0.564 & 0.139 & -0.598 & -0.850 & -0.670 & -0.412 & -0.765 \\
\hline $\begin{array}{l}\text { E.Conductivity } \\
(\mu \mathrm{m})\end{array}$ & -0.468 & 0.444 & -0.662 & 0.313 & -0.533 & -0.777 & 0.394 & -0.528 \\
\hline TDS (mg/l) & -0.323 & 0.707 & -0.413 & 0.620 & -0.206 & -0.560 & 0.706 & -0.183 \\
\hline $\begin{array}{l}\text { Turbidity } \\
\text { (NTU) }\end{array}$ & -0.234 & 0.267 & 0.502 & -0.308 & -0.535 & 0.209 & 0.043 & -0.374 \\
\hline Iron (mg/ l) & -0.010 & -0.071 & 0.874 & -0.247 & 0.046 & 0.519 & -0.028 & 0.184 \\
\hline $\begin{array}{l}\text { Sodium } \\
(\mathrm{mg} / \mathrm{l})\end{array}$ & 0.523 & 0.902 & -0.038 & 0.674 & 0.495 & 0.402 & 0.671 & 0.398 \\
\hline $\begin{array}{c}\text { Potassium } \\
(\mathrm{mg} / \mathrm{l})\end{array}$ & 0.504 & 0.726 & -0.236 & 0.919 & 0.759 & 0.183 & 0.680 & 0.678 \\
\hline $\begin{array}{c}\text { Phosphate } \\
\mathrm{PO}_{4}^{-}(\mathrm{mgr} / \mathrm{l})\end{array}$ & 0.070 & 0.771 & -0.509 & 0.922 & 0.299 & -0.331 & 0.745 & 0.292 \\
\hline Nitrate(mg/l) & -0.564 & -0.556 & 0.023 & -0.794 & -0.855 & -0.355 & -0.553 & -0.788 \\
\hline $\mathrm{DO}(\mathrm{mg} / \mathrm{l})$ & 0.653 & 0.657 & 0.143 & 0.644 & 0.718 & 0.599 & 0.445 & 0.728 \\
\hline
\end{tabular}

Table 3: Correlation between Relative Abundance of Fish Species and Physico-Chemical Parameters in Gubi Reservoir

Table 3 shows the correlation between Relative Abundance of fish species and the physico-chemical parameters in Gubi reservoir. Generally, there was negative correlation between the physico chemical parameters and the relative abundance of fish species. Increase in the value of physico-chemical parameters within biological tolerable limit brought about decrease in relative abundance, while increase in relative abundance which caused the decrease in physico-chemical parameter.

\section{Discussion}

The relative abundance of fish species indicated that Nile tilapia (Cichlidae) (70.1\%) was highest abundant species follow by Clarias garipinus (Claridae) $(0.68 \%)$, Silver fish $(0.17 \%)$ Schilbaidae $(0.02 \%)$, where Cyprinidae $(0.01 \%)$ was the least species abundant due to the fact of fishing pressure currently in the reservoir. the result of this study agrees with the finding of Komolafe et al. (2016), where they have pointed out that Food and high reproductive efficiency might be responsible for the abundance of the cichlids. Also, Moses (1974) suggested that the dominance of cichlids in Lower Nun River may be attributed to gear selectivity.

The mean, maximum and minimum value of physico chemical parameters of Gubi reservoir. These values were within the permissible limit of (W.H.O, 2008). The value obtained is indicated a good water quality (Boyd, 1998). However, this indicated that the water quality parameters are suitable for fish survival in reservoir.

The maximum mean values of surface water temperature were recorded in both Kwatan Yashi and spillways $(24.80 \mathrm{C})$ this could be as a result of present of anthropogenic activities, such as high input of agricultural fertilizer from farm, waste disposal, washing, bathing were found to be present around these sites. While the minimum mean value of 
surface water temperature was recorded in kumi $\left(24.2^{\circ} \mathrm{C}\right)$ this was due to less anthropogenic activities. According to Jhingran and Sugunan (1990), a reservoir having water temperature more than $22^{\circ} \mathrm{C}$ is found to be highly productive.

Dissolve oxygen (DO), falls within the recommended limit of world health organization (W.H.O, 2008). The DO level in the water habitat less than $3 \mathrm{mg} / \mathrm{l}$ suffocates the animal. In the present study the DO content varied from $10.5 \mathrm{mg} / \mathrm{l}$ in Tatumari to $(9.1 \mathrm{mg} / \mathrm{l})$ in spillway, which indicated a good water quality for fish survival (Boyd, 1998). The maximum mean value of dissolve oxygen (DO) $(10.5 \mathrm{mg} / \mathrm{l})$ was recorded in Tatumari and Kumi, this could be attributed to low atmospheric temperature. Similar trends were made by Adebisi (1981) and Deshmukh (2006). While the minimum mean value of dissolve oxygen (DO) $(9.1 \mathrm{mg} / \mathrm{l})$ was recorded in Spillway this was due to high atmospheric temperature.

The mean value of $\mathrm{pH}$ range between (7.49) in kumi and (8.16) in spillway, this indicated that parameters were within the normal range to support aquatic fish growth (Das 1996). The maximum mean value of $\mathrm{pH}$ (8.16) was recorded in spillway, this was due to present of anthropogenic activities such as waste disposal, high input of agricultural fertilizer, washing, bathing and fish processing were found to be present around this sampling site. While the minimum mean value of $\mathrm{pH}$ (7.49) was recorded in Kumi this could be as a result of less anthropogenic activities.

The maximum mean value of electric conductivity was recorded in Tatumari $(288.6 \mu \mathrm{m})$ this was due to as a result of high discharge of agricultural fertilizer, waste disposal, an increase of silt caused by soil erosion as a result of logging washing, bathing and fish processing which were present which accumulate the level of ionic concentration. While the minimum mean value of electric conductivity was recorded in kumi $(224.8 \mu \mathrm{m})$ this could be as a result of less anthropogenic activities.

The maximum mean value of total dissolve solid (TDS) was recorded in Tatumari (165.5 mg/l) this could be attributed to high disposal of solid waste, washing, bathing, fish processing and the input of agricultural fertilizer respectively, (Oladiji, et al, 2004). While the minimum mean value of TDS (142.2 mg/l) was recorded in kumi, this was due to less anthropogenic activities around this site.

The maximum mean value of turbidity was also recorded in Ba'ila $(27.0 \mathrm{mg} / \mathrm{l})$ this could be as a result of high disposal of solid waste, increase of siltation, caused by the runoff of erosion as a of logging, and the runoff of fertilizer and other domestic activities which were found to be present. While the minimum mean value of turbidity was recorded in Babban kwata (14.68 mg/l) this could be attributed to less anthropogenic activities, this has been reported by (Ezra, 2006).

The maximum mean value of Nitrate was recorded in spillway $(6.26 \mathrm{mg} / \mathrm{l})$ this was attributed to excessive run-off of fertilizer from farm which stimulated the growth of algae, waste disposal, silt erosion by logging, washing and bathing were present, (Heywood and Watson 1995). While the minimum mean value of Nitrate was recorded between Tatumari and kumi $(3.58 \mathrm{mg} / \mathrm{l})$ were due to the present of less anthropogenic activities. The maximum mean value of Phosphate was recorded in Tatumari $(15.3 \mathrm{mg} / \mathrm{l})$ this could be attributed to high influx of fertilizer runoff from the farm, waste disposal, washing, bathing and fish processing have been present around this sampling site, (Bugenyi, 1987). While the minimum mean value of Phosphate was recorded in Spillway (6.4 mg/l) was due to the less human activities.

The maximum mean value of sodium was recorded in Tatumari $(11.7 \mathrm{mg} / \mathrm{l})$ this could due to the high discharge of solid waste, influx of agricultural runoff fertilizer, washing, bathing was also to be present, (Olaniyan, 1969; Kemdirin, 1990; and Nwankwo, 1996). While the minimum mean value of sodium was recorded in spillway $(4.45 \mathrm{mg} / \mathrm{l})$ this could be attributed to less human activities.

The maximum mean value of Potassium was recorded in Tatumari $(7.2 \mathrm{mg} / \mathrm{l})$ was due to high input of agricultural runoff of fertilizer from the farm, waste disposal and other domestic activities were found to be present around this site, (Bugenyi, 1987). While the minimum mean value of Potassium was recorded in Spillway ( $5.0 \mathrm{mg} / \mathrm{l}$ ) was attributed to less anthropogenic activities.

The maximum mean value of iron $(0.58 \mathrm{mg} / \mathrm{l})$ was recorded in Ba'ila was due to the discharge of waste generation from fish processing, washing, bathing, and waste disposal, logging which increase the level of silt were found to be present around this site, while the minimum mean value of iron $(0.21 \mathrm{mg} / \mathrm{l})$ was recorded in spillway which might be attributed to less anthropogenic activities.

The correlation between Relative Abundance of fish species and the physico chemical parameters in Gubi reservoir. Generally, there was negative correlation between the physico chemical parameters and the relative abundance of fish species. Increase in the value of physico chemical parameters within biological tolerable limit brought about decrease in relative abundance, increase in relative abundance which caused the decrease in physic chemical parameter, the result from this study correlated with the finding of (Lomel,C.Kirstein, 2011).

\section{Conclusion}

The mean values of physico-chemical parameters were within the normal range for fish tolerance, growth and reproduction. The anthropogenic activities include overfishing, farming, waste disposal, logging, washing, bathing, and fish processing have been observed and identified around the sampling sites in Gubi reservoir. So far, these activities have no negative impact on the quality of water.

\section{Recommendations}

- Proper waste disposal should be provided and maintained.

- People should stop deforestation and intensified the effort of a forestation programme.

- Anthropogenic activities around the reservoir need to be checked to avoid the extinction of fish species in the nearest future. 
- Advisory teams of water quality should be established by riverine communities to control human influence of the water bodies.

- Farmers should be educated on better managerial practice, bordering of feeding practice.

- There is need a scale for measuring the degree of the impact of anthropogenic activities on fish diversity with respect to varying sampling sites in Gubi reservoir.

\section{References}

i. Acharyya, S. K. (2005). Arsenic level in ground water from quaternary alluvium in ganga plain and Bengal basin India subcontinent. Insight into influence of stratigraphy, gondwana research 8:55-66

ii. Ahmad, S.And Hussain, S. I. (2001). Snow and stream water chemistry of ganga head basing HimalayaIndia. Hydrological science journal, 46:103-111

iii. Abbas, N. And Subramian, V. (1984). Erosion and sedimentation transport in the ganga river basin India. Journal of hydrology, 69:173-182

iv. Adebisi B. A(1991). Hydrobiologia 79(2), 157-165.

v. Adebisi, A.A., (1981). The physico-chemical hydrology of a tropical seasonal river-upper Ogun river. Hydrobiologia, 79: 157-165

vi. Baghel, V.S. Gopal, K., Divivedi, S. And Tripathi, R. D. (2003). Bacterial Indicator of faecal contamination of the genetic river system Right at the source. Ecological Indicator, 5:49-56

vii. Bugenyi, F. W.B. (1987). Human activities and detrimental aspect inflicted on the Nile and its resources in Uganda. Uganda fresh water fisheries research organisation, fisheries research, fisheries cooperative building 10:20-21

viii. Boyd, C. E. and L. T. Frobish, (1990). Water Quality in Ponds for Aquaculture. Birmingham Publishing Co., Birmingham, Alabama, pp: 10-30. Aubura University, Alabama, 35pp.

ix. Boyd, C. E. (1998). Water quality for reservoir aquaculcure. Research and Development Series No. 43. international center for aquaculture and aquatic environments, Alabama, Auburn University publisher, Alabama.

x. Deshmukh, A. (2006). Journal of Aquatic Biology. 21(2), 93-96

xi. Ezra, A. G. And Nwankwo, D.I. (2001). Composition of phytoplankton algae in gubi dam reservoir, Bauchi state Nigeria. Journal of aquatic science, 16:115-118

xii. Ezra, A. G. (2006). Phycoperiphyton of Some Aquatic Algae in a Stream near Abubakar Tafawa Balewa University, Bauchi State, Nigeria. Journal of Experimental Aquatic Biology 7(2):117-122.

xiii. Food and Agricultural Organization (2014). State of the world fisheries and aquaculture. Romme FAO, 243pp

xiv. Froese, R. And Pauly, D. (Eds) (2014). Fish Base. World wide web electronic publication, available at www.fishbase.org.

xv. Heywood, V. H. and Watson, R. T. (1995). Global Biodiversity Assessment. Cambridge University Press. Cambridge UK. 322pp

xvi. Idodo-Umeh, G. (2003). Freshwater fishes of Nigeria. (taxonomy, ecological notes, sddiet and utilization). IdodoUmeh Publishers Ltd., Benin City, 232pp.

xvii. Jhingran, A. G. and Sugunan, V. V. (1990). General guidelines and planning criteria for small reservoir fisheries management. Jhingran, A. G. and Sugunan, V. V., 1990. General guidelines and planning criteria for small reservoir fisheries management. In: Reservoir fisheries in India.

xviii. Kemdiram, E. C. (1990). Periodicity and succession of phytoplankton in an upland and lowland impoundment in plateau state (Nigeria). In relation to nutrient levels and physical characteristics. Journal of aquatic sciences. 5: 4352.

xix. Komolafe, O.O., Olofinmehinti, M. O., Adedeji, A. A. and Adewole, H. A. (2016). The Distribution Composition and Abundance of Fish Species in two Abundoned Gold Mine Resources IGun, Osun State, Nigeria. Ife Journal of Science Vol. 18 no.1

xx. Lomei.C. Kirsten, (2011). Correlation between Fish Abundance and physic chemical parameters Humboldt Bay, California. Natural Science, fish Biology, 1-146 Pp

xxi. Moses, O. O. (1974). Aspect of the Biology of Asejire Reservoir. Ph. D. Thesis, University of Ibadan, Nigeria. 301pp.

xxii. Nanda, S. N. and T. N. Tiwari, (2001). A survey of fish fauna in the sambalpur-Hirakund-Burin region, Orissa. Environ. Pollut., 8: 43-44.

xxiii. Nwankwo, D. I. (1996). The algae of an estuarine matriculture site in south western Nigeria.Tropical fresh water Biology 5: 1-11

xxiv. Oladiji, A. T. Adeyemi, O. Abiola, O. O. (2004). Toxicology evaluation of surface water of Amilegbe River, Niger soc. Expres Bio, Bichem. 16.94-101.

xxv. Olaniyan, C. I. O. (1969). The seasonal variation in the hydrology and total planktonic of the lagoons of south west Nigeria. Nigerian Journal of Science. 3 (2): 101-129

xxvi. Wufem, B. M., Ibrahim, A. Q., Gin, N. S., Mohammed, M. A., Ekanem, E. O, and Shibdawa, M. A. (2009). Speciation of heavy metals in the sediments of gubi dam Bauchi state, Nigeria. Global journal of environmental science, $8(2): 55-63$

xxvii. World Health Organization, (WHO 2008). Guidelines for Drinking Water, WHO Criteria and other supporting information, World Health Organization: Geneva. 